\title{
Maori culture today
}

John Rangihau

From: The New Zealand Social Worker - News and Opinions; Vol.3, No.4-November 1967.

In order to get the ball rolling on this I suppose we need to have a look at what is meant by culture. Phillip Keesing says there are 159 different definitions of culture, so that it is something that has been interesting people all through the ages.

For our purpose I think it is easy to say that culture is a totality of learned socially transmitted behaviour. If we have a look at this statement we will see that people learn culture from the time they are born and this is transmitted to them by their parents, by the environment they are living in and by the people with whom they come in contact and with whom they must integrate in some way for any sociological climate or sociological aspect to happen.

It always does happen of course that you have some sort of sociological contacts in the problem of living, and below this you have people who, transmitting their feeling and attitudes, will transmit them into individual members of society and individual members of the family.

So you are not only dependent on parents and not only dependent on your own limited environment, but as years go by you are dependent on school teachers and other people to learn from or to look to, and who in some way or other influence your whole life and your whole attitude.

Culture is being transmitted in every situation. On this question of transmission you will of course have different values being placed on different things that you learn, and if you think of values as being emotionally charged preferences or standards of work, then you will see why sooner or later these values must at some time or another concern one another, especially if you are living in a multi-racial situation like ours.

There is in some cases a definite clash. If we look at it in terms of values as being emotionally charged preferences or standards of work, then we must at one stage or another be confronted with or probably have a clash because of the different values of the different value systems which one uses and which one has when dealing with culture.

In a situation like ours I want to have a look at Maori culture in this modern society, modern in the sense of 1966, and I also want to have a look at culture in the day of tomorrow. Various people have talked about Maori culture and especially what has been termed as Maoritanga, which is a word that has been used to explain in some way or another culture, especially Maori culture.

The Rev. J. G. Laughton wrote a paper which was very well received which debated facts on Maoritanga, and this paper was written by him for the National Council of Churches, and as an exposition of Maoritanga and values which Maoris are interested in and which they want to hang on to for as long as possible. 
I believe that this is the best exposition of Maori terms that I know of. It is very brief, and is done by a European and one who lived in a totally Maori situation for some years and had to watch his every move because this situation he was living in was fraught with not only danger to himself, but fraught with the possibility of his having to leave very hurriedly if he did not watch his Ps and Qs.

Here was a Minister with very set ideas, in a situation where his every action was examined very closely under the microscopic eyes of Maoris living in that area who were then going through a period of religious resurgence. Religious in the sense that one of their members had proclaimed himself to be a Prophet and for this reason people from all over the particular area flocked to this particular place and there were possibly 2500 to 3000 people living there at that particular time.

He was then able to live in this situation for a number of years and he himself admitted that sometimes he was sailing very close to the wind and whenever he preached his message he had to preach it in rather a detached manner and not go down and exhort the people to change their ways because the situation was fraught with all sorts of possibilities as far as he was concerned. He had to learn very quickly this idea of getting on with the people and living with them at that particular time.

One of the first things he says about Maori culture is that Maoris when they are talking about themselves are not saying 'I am I', but are saying 'I am we'. In other words, he was part of a larger community and he was not an individual person and everything that he did was dependent on how the group looked at it and censures which were given him were given him on the group angle and for a long time he did not realise this was such a potent force that he had to talk to people and in terms of the total community.

He could not individualise any thing that he did, so this was one of the first concepts as he saw it, that the Maori spoke of himself as 'I am we' rather than the usual manner of other people which is 'I am I'. That first concept, as he saw it, was a concept of people working, living, playing and laughing together, of everything being done for the group and that each individual member was only looked on as a part of the group and he felt that this was the most vital thing so far as he was concerned about Maori culture.

In the present stage of our development people have been talking about integration and one suspects, especially a Maori suspects, that integration in some people's terms, is straight out assimilation.

Numbers of Maoris have to learn to live, to talk, to act, and have attitudes and think as Europeans, and I suspect that in some quarters this would be the ideal situation. But, by and large, integration has been taking place ever since we were confronted with cross cultural contact and two peoples with different values coming together.

Since that time in 1840 and beyond, integration has been taking place, and as far as I am concerned, integration is here and is a fact, and also as far as I am concerned, we are here as New Zealanders because we are New Zealanders.

We are New Zealanders by reason of the fact that we are living here, we are New Zealand- 
ers by reason of the fact that we want to stay here, and people talk about the ideal situation of all of us becoming New Zealanders at some future date.

It is a highly idealised position, for not only are we all to become New Zealanders, but most of us will have learned and have been educated to the extent that we will only have people who think in terms of European values and European standards.

I cannot agree that this is the last thing for us to do, nor can I agree that it must happen at some future date. What I am saying is that it is happening now and it has been happening since we two people came together.

We have learned through intermingling, we have learned because we have been thrown together in so many different ways.

Dr Metge talks about the fact that we go to the same pictures, we do the same sort of things at every stage and at every stage there is some social integration between Maori and Pakeha, and I believe that this is correct, but within this total framework of social integration there must be room for people themselves to be able to express themselves in the way they want to and this is the way that I see Maori culture in the future.

Carrying it a bit further about concepts of Maori culture, one of the most important things of any culture is the language of its people. I have stated in other places and on other occasions that I would think that there are less than 50 per cent of Maori people today in New Zealand who are Maori speaking. In a place like Rotorua, which one would normally think is a very strong Maori settlement, and it is in some other aspects, but in the region of language Rotorua comes out as a very poor example because, of the people under 20 years of age, 90 per cent will not be able to speak Maori, and, of those under 15 years of age, 98 per cent will not be able to speak Maori, and here in a region where we have strong Maori points to culture and yet here we have the fact of the language losing out.

I do not believe for one minute that if it were possible for the language to be taught at the schools that this would be sufficient. Were it possible for the educationists and Government to realise that Maori should be taught in schools then I suggest that we would only be beginning in this whole business of Maori language.

It has been said that the Maori language is a very limited one insofar as it cannot be used in this highly technical world of ours and that it cannot in fact define many of the words which we use because of the vast technical changes, and I suspect that this is true. But in spite of the fact that they will not be able to come down with a single word for explaining certain things like neutrons or protons and what have you, I still am of the opinion that if Maoris felt they had to explain such things to people who could not understand English, then they could explain it.

Of course as you know one of the things about Maori language is that we do not believe as a people that it has any place in our society or is of use in itself. We do not believe as a people that we will get any advantage from using it. But we do as a people believe that we should have some from other European languages and there is a lot of movement for learning the Asian languages. 
I am always struck by the fact that people going overseas are interested in Maori people and the way that we have been able to mix and intermingle together. Yet it is not worth our while to talk the Maori language.

I am one who contributes to the view that we do not have to know the language in order to be Maori. Some six or seven years ago some people in Victoria University, a mixture of sociologists, psychologists and anthropologists, as one of their exercises tried to measure the amount of Maori there was in any particular Maori.

In trying to measure this they came up with 20 different questions and it depended on how the person who was being asked these questions answered them, and it depended how far they could answer.

They could then assess the amount of Maoriness in this person. Presumably if a Maori person could answer the 20 questions in the way that they had put it down or marked it, then this person would be 100 per cent Maori and so on down the line, so that you had some ideas to the amount of Maori there was in a certain Maori. It is interesting to note that these questions that were being asked were very simple ones which absolutely took the wind out of the sails of a lot of Maoris because they had not thought about it in such a way, and it became quite interesting when giving it to Maori people to see the sorts of reactions that they had.

Some became very aggressively inclined towards the question and some of them lost all sense of equanimity and became quite coy, and it was quite interesting to see how people reacted in this way. The only reason I bring this up is because sooner or later I suspect this whole people will be looking at Maoris in the future, and especially Maori people themselves, and it will not matter whether you can by assessment of these criteria become Maori, because you can elect to become a Maori if you wanted to, and of course this is happening every day. So language, although as I said is one of the most important things, it is not the only thing that will give you a sense of having Maori culture because this must be taken in with a lot of other things.

I am also reminded of the Rev. Kingi Ihaka who debated this question of Maoritanga, saying that, as far as he was concerned, a Maori was a person who could talk Maori, knew the customs of the people, and looked Maori. At this particular meeting a number of South Island people got up very quickly on their feet and of course they looked so fair that you did not think there was much Maori in them, and they took him to task and said 'I do not know how to talk Maori but you cannot tell us we are not Maori'.

Another important aspect of Maori culture is conveyed in the term Turangawaewae.

Turangawaewae has always been centred around the Marae. Whereas previously it was centred around the common ground of the tribe, over the years it has had to modify itself. I think it has reached a stage where this is the Marae and the Marae is that area of clear ground which is immediately in front of the meeting house or any of the buildings appertinent to the meeting house. It may not be a meeting house as we know it, I have seen meeting houses throughout New Zealand and in some areas, principally in North Auckland, they have no meeting houses as we know them, they have what would be a Community Centre, where 
everything is housed in a hall-cum-meeting house building where everything is under the one roof. But whatever it is, this allows them to be able to say what they want to say and this also allows them to feel identified with the particular home area that they come from.

Turangawaewae I suppose is that emotion that the land has for the Maori and the tie is emotional not because the Maori sees land as being something that you can use, or as they do see it now as being something negotiable, but he sees the land as the place from whence he has come - mother earth and father sky. This is part of his mythology and this gives him this emotional overtone to the land, that over the years he has lost so much of, and has had to learn to have his feelings centred around that place which he feels can never be lost. That is the Maori. The fact is that he is losing the Marae also.

Along the Taupo-Atiamuri road at a place called Maroa, if you turn right and go for about three miles you will see a meeting house in the middle of nowhere with nothing around it, no people there. A very fine looking meeting house, and it is just standing there, the Marae for the people in that place, and yet absolutely deserted. I suspect that there will be a lot more of these in the future so that the concept of Turangawaewae will have to change, and it is changing. Previously they centred around land around their home areas and thus it progressed to the Marae. I think it will progress a bit further to that area in which he is living at the moment. If you can get the ideas, as to a British person this is his home or castle or village, a very sacrosanct place of ground, and here he is master.

I suspect that this is changing also for the Maori and that he has learned so well that he has become so individualised to the extent that he can also put this Turangawaewae and all that it means on his house. We know that one of the things that happens on the Marae is the institution of the Tangi and the Hui, and these two functions help to perpetuate and sustain those portions of Maori culture that cannot be done under any other circumstances.

It is at these functions where you will get people to chant their old chants, it is at these functions that you will hear the old monotone songs being sung. It is also at these functions that you will hear genealogical lines being traced. So the Tangi over the years has taken the place of the Wharewananga of the old schools of learning that the Maori had.

Wharewananga as such has been wiped out of existence because of the need to keep up with the economics of New Zealand, and in some way or another the Tangis have been the functions at which they relive or regenerate all these old things. It has been said by a lot of young Maoris that unless the old people are prepared to allow them to learn these things then they will be lost and a lot of them have already been lost. I contribute to the view that this is as it should be, because if it has no meaning, and if it has no place then you cannot make it live just for the sake of making it live, and where they should live is in the institutions and universities where they are being kept intact and this is where they should be.

If you cannot keep pace with the economics of the country or the standards of the total of New Zealand, then it cannot have its place in that particular area because it will set up tensions and difficulties between the Maori and the non-Maori as tensions and difficulties have been set up already, and are being set up already, because of other different values which we will touch on. If the young Maoris themselves feel that they cannot keep up with these things they should not be allowed to use these things so young Maoris of the future 
can become neurotic just because they cannot learn their old songs. But if there are sufficient Maoris who want to learn them because it has meaning for them, then they will learn them and will learn sufficient for them to get on.

There are any number of things in this category of songs which young Maoris will not be able to recite or to give out in the old form. The language has become difficult for them to learn, the words and the use of them have become difficult because they have now learned to use English words, and even people my age who speak Maori very well, immediately they start to recite these things the older people immediately say that they are losing out on Maori and I have been told this on so many different occasions - by my own mother when she was alive, and by other people, and yet as one of those who thought I had very good Maori.

The fact is that we are losing it and we cannot get round some of these things, so it is not right that we should become neurotic by trying to get our tongues round it. If they cannot stand the test I for one think they should go. Things have changed, and now you find Tangis being held in private homes. It has not reached that stage in Rotorua, although quite recently I heard of one case where the children were not happy to take their father to the Marae and they had the Tangi in their home. A few years ago you would not have thought that possible in Rotorua. A few years ago the Rotorua people themselves would have been up in arms, but this was last year and this happened to a man who comes from Ohinemutu and they allowed him to lie in state at his home, so that it is changing even in places like Rotorua. But all that has happened in a Tangi at a Marae and has now happened in a home was that the emphasis had shifted from the Marae to the home, and people say that Maoris should cut adrift from all their tribal ties and in fact they are cutting adrift.

Where previously Maoris used to come back from Wellington in order to go to the Tangis here, they are becoming less and less involved in this situation and this is simply because of the economics of trying to get back up to Rotorua from Wellington, where it costs at the least $\$ 12$ and possibly with all that you have to do on the way up it could cost $\$ 20$. People who are earning no more than $\$ 30$ a week find this a real hardship. So in actual fact ties are being cut because this is the way that we have to live and because we have to fit into the economics of the situation.

Finally on Maori culture I include such a large body of things that come in Arts and Crafts, but I think it is in this area that most of what people would like to retain as being part of Maori culture. I think it is in this region that they will retain it because these are the things that you can see and do and enjoy doing in a group, and they do it in a group.

I am speaking specifically about action songs and hakas. It is very interesting that in discussing physical fitness with Professor Smithells one evening, who is head of the Physical Education Department at Otago University, he said to me 'For some time now I have been trying to include hakas and action songs in the curriculum because I feel that here are things which are suited to the development of the body. The natural grace of action songs and the movements of the hands and feet, co-ordination of actions to harmony' and this he thought was the sort of things the students could learn in terms of physical education. Then he went on to say there is nothing more vigorous and more testing than doing a haka properly and he saw elements in it which could fit very well the sort of thing he was doing. 
In fact he was then trying to introduce it into his classes at Otago.

So that if you look at this as quite apart from the other and particularly in terms of training in physical fitness, training for grace, etc. then I believe that it should be done in all our schools as part of the physical education. I do not know whether they still do it, I used to go scampering madly round doing folk dances in my young days. In looking back on it I would sooner have been doing hakas and action songs.

Going back to what the Professor said to me, I thought how true it is that in fact you can do this sort of thing if you can introduce them into the school curriculum and it becomes part of the school and part of New Zealand.

It is a fact that we as New Zealanders will be trying to develop our own particular unique qualities which set us apart from other people.

Sometimes people from overseas think that we are inclined to be a little smug about our qualities - why not? We have a lovely country and we enjoy it to the full. Eric Linklater who wrote about his travels in New Zealand, in trying to assess the New Zealand character said that for him New Zealand character was a most hospitable person, in fact hospitable almost to the point where they embarrassed you, where morning tea was a big meal, afternoon tea was a bigger one still, and in between you had to eat all the other things. He felt that they were generous, that they were happy and friendly, and they were inclined to have a 'she's right mate' attitude, and he thought that in some cases they showed some shallowness because they were not artistic enough. I thought 'an expert looking at the New Zealand character.' And sometimes I find my New Zealand non-Maori friends looking at me in the same way.

They say that this 'me' as a Maori is inclined to be hospitable, generous to a fault, and yet here are English people looking at us. What has happened is that somehow or another you have taken from us all these things, and non-Maoris now tend to take these into themselves and to be now forming a New Zealand type character.

What you have done is taken the best part of Maori and introduced it to yourself, and well and good, but we should now ask a bit more and be a bit more active. I would say that it is not right that we have done these things to you but it seems right that we have this sort of characteristic. It seems right that people overseas tend to look at us this way and it is right that this is a New Zealand character.

So it is this New Zealand character that we should be encouraging, encouraging it so that not only will we stand out when accosted by someone in the middle of Picadilly or anywhere as being a New Zealander, but immediately we start to talk and to meet people they pick us out as being New Zealanders. And here in the Maori people, in the ethnic group of the country, ethnic only in the sense that they have been here a bit longer perhaps, here there is opportunity because they at least have certain cultural things which are essentially peculiar to New Zealand and nowhere else and here if we want to encourage the ideal of a New Zealand character, you have fertile ground on which to use this type of thing because it is peculiar to New Zealand. Despite this, however, the Maori has gone more than half way to meet the non-Maori. 
Perhaps we are a bit slower than most, perhaps the evolution has been much slower than we would have it and want it but the fact is that Maori has got more than half way. He has had to, not because the non-Maori has said to him, 'Look, if you don't go this way then we will leave you flat', but because he has had to follow the general stream, he has had to follow the things that every other person in New Zealand must do in order to live properly and he has had to follow because only then has he been able to raise his standards. And it is by reason of his standards that he will become a better citizen.

Now on the other side, the non-Maori has not in the past been actively concerned about not only stretching out a hand and helping the Maori, but going a bit further over to his side and saying, 'Look there are things about your culture that I like, what about teaching me', and what happens now is that immediately a non-Maori says this a Maori will look at him and say 'What do you want of me?'. Unfortunately because this is the way that he has had to learn in the past. Every time a non-Maori makes the approach the Maori will look at him and say 'Well, what are you after, or what is it you want', and it is only after a lot of social intercourse between one another that he comes to accept the person as wanting to learn out of genuine desire to do so.

I have said to Maori groups that there is a lot of latent goodwill throughout New Zealand on the part of the non-Maori but it is this sort of latency which needs to be awakened and it needs to be awakened because I believe that Maori culture has a place today and tomorrow. They must try to encourage this culture in such a way that it looks and becomes attractive to the non-Maori. I am one who would like to see it developed as I said earlier as being a New Zealand personality and New Zealand culture rather than a Maori one.

People have said that Maoris have become very difficult to deal with because they cannot dismiss the tribal affiliations. This is true. There is still a strong tribal feeling that the people have. While it is true that it is strong, it is equally true that it is missing out and really fighting a losing battle because young Maoris, especially from the age of 30 down, are not really interested in this tribal affiliation.

Whereas previously the Maori boy and girl not only knew what tribe they came from but could tell you what sub-tribe they came from, now they just vaguely know they come from a particular tribe and all they are interested in is that they are Maori. I have always been of the opinion that the first things Maoris must do in order to have their culture accepted by the non-Maori is to ensure that they themselves start thinking in terms of Maori as a whole and not tribal affiliations. That they get rid of all the tribal affiliations and regard one another as Maori persons and not Arawa first and Maori second, but Maori first and Arawa second, and I suspect that is now starting to go this way.

As I said, there are very few Maoris under the age of 30 who can really say 'I am from Sub-tribe so and so, and to prove this all you have to do is to have a look the Electoral Rolls and see the number of people who put down their tribe as being Arawa and never the sub-tribe, whereas if you had a look at previous electoral rolls you would always see the sub-tribe - so that they are losing it. If it can be replaced by the feeling of Maori and not in the nationalistic sense, but by feeling it is right to be Maori, and to have different things, then I suspect it will be well on the way to being able to present parts of our culture to the non-Maori in a more attractive form. 
We have agreed that for Maori culture to become a force in the future it must be so dynamic as to modify itself so that it becomes meaningful in future ages as it is meaningful to us today. I believe that this has no bearing on the nationalistic feeling as such but it is clearly an effort to prolong one's identity and the identity to be prolonged in such a way that it does not oppose progress, nor does it imply that it opposed integration of the two races. Integration of course has been happening for such a long time. I believe that integration has taken place and is still taking place for many of us. But what it does imply is that there are features of Maori culture that can be absorbed by the general public of New Zealand in such a way that Maoris themselves become easily identifiable and those who have lost their identity on a physiological basis can if they so elect identify themselves with either group.

I say a physiological basis here because the effects of intermarriage are such that in future generations there will be a lot of very fair Maoris, there will be very few full blooded ones. You see that happening now. One of the interesting things lately which some of the departments have been looking at is the fact that so many Maoris put themselves down as full blooded knowing full well they are not, that somewhere along the line their grandfather or grandmother has married a non-Maori. But immediately they look Maori they put themselves down as full blooded. Even in cases where we ask people what they are - say for housing purposes - they say Maori but you can see very well that there is a nigger in the woodpile somewhere. But this is the way people talk about themselves and this is the way that they should be allowed to express themselves. But I believe that intermarriage is playing such a big part in the change and this is why I am saying on a physiological basis, they can if they so elect identify themselves with either group, and people do identify themselves with either group.

I have seen so many and I suspect that some of you may have met them, many very fair people who identify themselves with a Maori group and I have seen so very many dark Maoris who try to identify themselves with the other group, because they cannot look like Pakehas anyway, but they are trying to identify themselves with the other group.

What we as Maoris must be able to do now and in the future, is to prove to the younger generation that the features of Maori culture we would like to hold are those ones which fit in quite naturally with the economic structure of New Zealand and at the same time provide creative aesthetic portions of the culture to interest all New Zealanders of the future. We must assure ourselves that any sense of derogation about aspects of Maori culture are discarded and replaced by modifications which can be accepted by all New Zealanders. This is what I am saying, that unless the Maoris themselves are actively participating in this whole business of interpretation and explaining how they feel and what they want to do, then it is most difficult for the non-Maori to see.

Finally I just want to touch very briefly on what I would term 'Spirituality' as being one of the concepts of Maori culture. This is not peculiar to the Maori but it is peculiar in this way, that ever since Christianity has been introduced to New Zealand Maoris have looked upon their religion as something which they can carry about with them. This God is not a God which lives up in the sky and which can only be met on Sunday morning in church.

This God is one that he takes round with him. His every movement is dependent upon asking divine guidance. Under what other conditions or where else can you find meetings, 
and very aggressive meetings, being opened by prayer and being closed by prayer, you only see this in the Maori situation. Every meeting that is held on the Marae must be opened and closed by prayer because they themselves believe their God is part of themselves and he is peculiar to him or to her. They carry him around in their pockets.

I mean this to be literal and I believe that this is the carry over from the days when so many of them were not allowed even to talk about Io which is a person to whom they gave certain attributes like those of the present day Jehovah, and in order to make their religious beliefs as such meaningful to them they set out carrying their little gods in their pockets - Kumara gods, etc. One of the strangest things, I suppose not too strange, is that Maoris (especially in Maraes) are quite happy to participate in whatever church is having a service at that particular time. They participate to the full in all these services, and one of the most interesting things that I myself am concerned with at the moment is that we are trying to give expression to worship in a Christian way as Maoris do so and would like to worship, and we are trying to introduce this by having a look at the constitution of the particular people that I am part of and we have said this quite clearly, that we would like to express religion in the way we would like to and would want to. That for us religion does not mean dressing up to the hilt and going along to Sunday service where you become part of the cold building, and sometimes cold people, cold in a sense that where you met them earlier and were able to talk to them on very close terms, in the church there seems to be a cloak of respectability about them and this is one of the things that we are trying to get away from because to us religion is something less austere.

I am not in any way saying that this is wrong because it fits the non-Maori people, but all I am saying is that this type of worship does not fit the Maori. And I am saying this because he regards his God as not being in the church but as being wherever he goes or whatever he does and this is one of the things about Maoris that perhaps we may be able to influence a non-Maori in some way.

Finally, I want to say I realise that really the best way to do this is to teach by example, by example I am talking about Maori culture and by example means that we become good Maoris and good New Zealanders because I have said that we are New Zealanders anyway. If by being this good, satisfied and wholesome personality we can influence the non-Maori this is the way I see Maori culture and this is for me the future of Maori culture in New Zealand. 